\title{
The Narrative Structure of Ambiguity A Semiotic Analysis of a Tawriya-Epigram by Ibn al-'Ațtāar (d. 794/1392)
}

\author{
Luca Rizzo \\ (Università Ca' Foscari Venezia, Italia | Westfälische Wilhelms-Universität \\ Münster, Deutschland)
}

\begin{abstract}
This paper engages in a semiotic analysis of a tawriya-epigram by Šihāb al-Dīn b. al-Atțār (d. 794/1392). Mamluk literature is renowned for its extended usage of figures of speech, above all the tawriya, 'double entendre'. The goal of this articole is to shed light on the tawriya, taking into account the Arabic classical theory and presenting a new approach based on semiotics. The subject of my analysis is the most flourishing literary genre of the epoch: the epigram. Within the epigram, the tawriya plays a pivotal role. Its potential is not limited to a twofold reading of the text but rather goes further and creates a second text out from the first, both of which cooperate with one another and shed light upon their respective meanings. Therefore, the epigram by Ibn al-Atțār is a construction of several texts, each of which is mutually linked and deeply-rooted in the social and physical environment depicted in the poem: the hammām.
\end{abstract}

Summary 1 Introduction. - 2 A First Look. - 3 The Isotopy-Disjunction Model. - 4. The Narrative Schema. - 5 Applying the Semiotic Square. - 6 Space as a Text. - 7 Conclusions.

Keywords Tawriya. Epigram. Mamluk Age. Semiotics. Ḥammām. al-'Aț̣ār

\section{Introduction}

The epigram in pre-modern Arabic literature was a widespread literary genre, especially in the Mamluk age, during which almost every litterateur composed epigrams. Van Gelder defines it as "a short poem with a witty turn of thought" (2012). He also underlines that the Arabic terms for epigram, such as maqțúc, maqțü'a, qiț'a, or muqațt'a, derived from the same root, meaning 'to cut - to cut off', which suggests, wrongly, that it is a part of a longer poem. Although the nature of Arabic poetry itself allows it to isolate a number of verses with self-contained internal coherence and meaning, epigrams were composed as stand-alone poems. In a recent monograph, Talib (2018) provides a coherent analysis of the epigram as a genre, the establishment of which took place by the eighth/fourteenth century. In the analysis of its structure, Talib argues that the operational 
logic implied in a maqțúc pl. maqāțī' is the formula premise-expositionresolution:

most maqāțī follow a structural formula, and although no classical Arabic description of it survives, it is both distinctive and unmistakable. Maqāțī' begin with a proposition (or premise), which is then developed and fleshed out, and by the end of the poem, usually at the very end (the point), the premise is resolved, often with a witty turn of phrase (resolution). (Talib 2018, 23)

To explain its vast and flourishing development, Bauer (2013a) interprets the epigram as a 'participated text'. In doing so, he posits three main theses as to why the epigram experienced so wide a diffusion. First, it is a literary form which is highly communicative, spurring the participation of the public to the creation of new pieces of poetry. Second, the epigram is based on the cooperation between author and hearer/reader, ${ }^{1}$ involving both in an operation of encoding and decoding. Finally, its deep roots in the social context of the enunciation, out from which it arises and takes its motifs. Another characteristic of the literature of this period is the extended use of figures of speech, above all the tawriya 'double entendre', which was one of the most common rhetorical devices of the time. It developed as a result of its intrinsic and implied cooperation between author and reader - grounded in the reader's encyclopaedia - according to Eco's theory of the cooperative interpretation outlined in Lector in Fabula.

At this point a few questions arise. Taking for granted that the epigram is to be considered as the principal literary genre of the epoch, and that the tawriya as a figure of speech saw greater diffusion than its counterparts, which level of analysis should be employed to explain how a tawriya-epigram works? Moreover, how can we depict its link with the social environment, without which both the tawriya and the whole epigram lose the possibility of being interpreted and understood? In this article I focus my attention on the following tawriya-epigram by Ibn al-'Atțār al-Mișrī (d. 794/1392), ${ }^{2}$ in which the play concerns (possible) male-male

I want to express my gratitude to Professors Thomas Bauer, Antonella Ghersetti, Syrinx von Hees, and Tiziana Migliore for their precious advice, as well as to all the members of ALEA group. A special thanks to the anonymous reviewers for their remarks, and to Dillon Banis for his constant help.

1 Despite the original oral nature of Arabic poetry, from here out I will address both the hearer and the reader as reader, according to the terms of reception theory. See Eco ([1979] 2006) and also Iser (1980)

2 His full name was Aḥmad b. Muhammad b. 'Alī Šihāb al-Dīn Abū l-'Abbās b. Šams al-Dīn al-Dunaysirī (also called al-Qāhirī l-Šāfi'ī), known as Ibn al-'Ațțār al-Mișrī. Ibn Tag̉rī Birdī (1984, 
intercourse in a public bath, a hammām, but in a private space within it, a halwa.

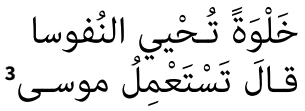

Hayya'a l-ballānu Mūsà Qultu mā așna'u fì-hā?

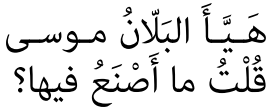

halwatan tuhỵì l-nufūsā

Qāla tasta'milu mūsà

The bath attendant Mūsà prepared a secluded place, which revives the souls. I said: "What should I do in it?" He replied: "You use a Mūsà/razor!"

Ibn al-'Atțār's epigram was not the first, nor the last, piece of poetry playing on the name Mùsà; this motif seems to have been an easy and popular pun since ancient times. A perusal of the sources shows that many lines of poetry use the name Mūsà in different ways for different aesthetic goals. Take, for example, puns on the homonymy of Mūsà-razor, which sometimes also play on the names of the prophet Moses and his brother Aaron. To my knowledge, the oldest example is attributed by al-Șafadī (d. 764/1363) to Abū l-'Atāhiya (d. 210-1/825-6): ${ }^{4}$

2:177-9; 1992, 12:99; 1998, 1:85), al-‘Asqalānī (1972, 340-2), Ibn Qāọī Šuhba (1977, 1:434-6), al-Maqrīzī (2002, 1:203-6), Ibn al-'Imād (1992, 8:569), GAL (2:14-5), al-Lahībī (2014, 222-5). The biographers report that he was born in Cairo in 746/1345 and was talented in several sciences. He started composing poetry at the age of thirteen and composed approximately

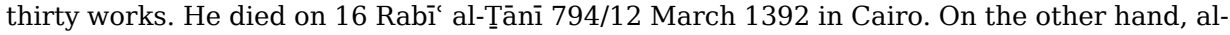
'Asqalāni says that he was born before the year 740 and ascribes to him a lack in the Arabic language, as Ibn al-'Imād also does, charging him with solecism. He was famous above all for his epigrams, but he also wrote a badī'iyya, muwaššahăt, hamriyyāt, love poems, and in praise of the prophet. See the given bibliography for the list of his missing and surviving works.

3 This epigram is quoted by al-Ġuzūlī (2006, 2:322), Ibn Hiğğa (2001, 3:482; 2011, 226), al-Nawāğī (Marāti` al-ġizlān. Topkapi, TKS. 722, f. 39v; Gotha, Ms. Orient. A 2314, f. 44v; Escorial, 339, f. 48r-v), al-Haymì (1986, 101-2), and al-Lahībì (2014, 245; 261). The editors of Ibn Hiğğa's works read al-ballāna instead of al-ballānu. This has to be considered the lectio dificilior. However, in al-Guzūlī we read wa-qāla Šihāb al-Dīn Ibn al-'Atțāa fì ballān yud'à Mūsà (Šihāb al-Dīn Ibn al-'Atțār said about a bath attendant called Mūsà); in al-Nawāğĩ and al-Haymī we read qāla fí ballän ismu-hu Mūsà (He said about a bath attendant whose name is Mùsà). I adopt this lectio facilior, as does al-Lahībī. In Lisān al-'arab (s.v. "b l l") only the sense 'hammām' is mentioned, while in Täğ al-'arūs (s.v. "b l l") we find also the sense 'bath attendant' supported by a quotation of two lines attributed to 'Abd Allāh b. 'Abd Allāh b. Salāma l-Idkāwī (d. 1184/1770): hayā li-ya l-ballānu mūsà/halwatan tuhyī l-nufūsā | qūla mā ta'milu fi-hā/qultu asta'milu mūsà. I am not able to give a convincing syntactical explanation for the reading al-ballana, and I adopt the reading al-ballanu which seems to be the only valid on both syntactical and semantic levels.

4 Al-Șafadī 2009, 284. In Abū l-'Atāhiya's dīwān the line is not reported, see Abū l-'Atāhiya 1909; also Dīwān Abì l-'Atāhiya 1999. This line is also quoted without any attribution in alRāg̣ib al-Ișfahānī 2012, 3:664; Faḩr al-Dīn al-Rāzī 2004, 61; al-'Alawī l-Yamanī 1914, 2:372; al-Subkī 2001, 2: 386; al-Taftāzānī 2013, 689; al-Suyūțī 2015, 405; Ibn Ma'ṣūm 1968-69, 1:219. 


$$
\text { وبهارونَ إذا ما قُلــبا }
$$

حُلِقَتْ لِحْيَةُ موسى بِاسمهِ
Ḥuliqat liḥyatu Mūsà bi-smi-hi

Mūsà's beard has been shaved with his name wa-bi-hārūna id̄ā mā qulibā

and with Hārūn when inverted

The line is quoted as an example of ğinās - or tağnīs - al-išāra or al-ğinās al-ma'nawì. This figure is depicted in the first hemistich: it is the use of the expression bi-ismi-hi, instead of the repetition of the word mūsà, the meaning is thus expressed 'Moses' beard has been shaved with a razor'. The second hemistich presents another word play: an inversion. Al-Siyālkūtī (d. 1067/1657) ${ }^{5}$ quotes the second hemistich in another verse and explains that if we invert - qalaba - the letters of the word hārūn we obtain nūrāh, which means razor in Syriac language. Moreover, the long vowel à in hārūn is often not written, resulting in the inversion nūrah - نورة. This word means depilatory paste - used for shaving -, which is, in my opinion a preferable reading for the second hemistich. What is more, there is still the allusion to the prophet Moses and his brother in the background, even if it does not play an active role in creating these two word plays. Many other examples could be mentioned, in total I could find seventeen of them in a range of time from the fifth/eleventh century until the eleventh/ seventeenth century. ${ }^{6}$

Ibn al-'Atțār's epigram, however, is a representative example of the use of tawriya in a muğūn epigram, ${ }^{7}$ and its analysis will prove to be fruitful. Nonetheless, my investigation is far from providing a comprehensive and universal theory of tawriya-epigrams. My intent is to put forth a semiotic study of a tawriya-epigram, which takes into account several relevant theories.

Moving from the premise that "inside every text there is its content, but also the image of its communication (enunciation): the principles for its functioning, the criteria of its production and reception, in other words its

Clearly the attribution is not credible, but the quotation in al-Iṣfahānī proves that this line is probably prior to the beginning of the fifth/eleventh century - on his date of death see Rowson, E.K, $E I^{2}$, s.v. "al-Rāghib al-Ișfahānī".

5 Al-Siyālkūtī 2012, 462.

6 Of course, it is very likely that many more examples could be found enlarging the corpus of consulted sources, and I am planning to address this topic in a future work.

7 "Mujūn is any text or behaviour which is meant or perceived to constitute a breach of ordinary norms of writing or conduct, and which is meant or perceived to be jesting rather than serious" (Szombathy 2013, 308). See this author for a comprehensive study of muğūn. 
instructions for use [Author's italics]" (Marrone 2014, 86 ), my purpose is to shed light on this functioning, in order to (re)discover the agency of the text on its audience.

To address the topic, I posit a first contextualisation of the epigram and describe its reading and analysis accordingly with the Arabic classical theory of tawriya in the first part of this article. The second part moves to a structural analysis of the narrative, by which I compare and highlight the similarities of this epigram with the histoire drôle studied by Morin ([1966] 1981). For this, I apply the Isotopy-Disjunction Model. The third portion presents the narrative structure of the epigram, in order to retrace its narrative schema and its actants. The fourth section introduces structural semantic theories, including the application of the semiotic square to the epigram, in order to link it with its social environment and explain the estrangement provoked in the reader. Finally, the last part describes how the semiotics of space applied to the environment of narration is able to explain how the space hammām is to be considered as a text within texts, all participating in mutual interaction.

\section{A First Look}

Bonebakker (1966) was the first scholar who devoted a seminal work to the study of tawriya, a figure of speech which saw such wide a diffusion during the Mamluk and Ottoman ages. Basing his analysis on al-Ṣafadī's Faḍ al-hitām, he traces the history of this figure of speech starting with the sources dealing with tawriya prior to al-Safadi's time. He then moves to the analysis of the theoretical part of Faḍ̣ al-hitām and concludes his essay with an overview of relevant later sources, which add several details to al-Ṣafadī's system.

According to the accepted definition of tawriya - detailed in many sources, the most important of which are al-Șafadī and Ibn Hiğğa (d. 837/1434) - it is a word, or a phrase, with two meanings, the first of them called al-ma'nà al-qarīb 'the near meaning', which is immediately understood by the reader. The second, called al-ma'nà al-ba'ìd 'the distant meaning', being the one intended by the author, is not immediately understood. ${ }^{8}$ To one of these two meanings, one or more 'attributes' can refer: they are the lawāzim sing. lāzim, i.e. a word or a phrase which can be mentioned

8 Al-Ṣafadī $(2013,75)$ quotes al-Sakkākī $(2014,537)$ : al-īhām huwa an yakūna li-lafž isti 'mālān qarīb wa-ba'īd fa-yuḍar li-īhām al-qarīb fì l-ḥāl ilà an yazhara anna l-murād al-ba'īd (The īhām [i.e. another technical term used for tawriya] is an expression which has two common senses, a near and a distant. [The expression] is mentioned to suggest first the near sense, until it becomes clear that the intended sense is the distant). Ibn Mālik $(2001,252)$ and al-Qazwīnì (2007, 348), give similar definitions using tawriya instead of īhām, and ma'nà pl. ma'ānī in- 
before or after the tawriya-word. Their role is to help the reader figure out the tawriya-word and understand the distant and desired meaning. Depending on the presence and reference of the lāzim, Arab theorists classified tawriya in four categories: ${ }^{9} 1$ 1) Tawriya muğarrada 'bare tawriya' presents no attribute related to the meanings of the tawriya-word; 2) Tawriya muraššạ̧a 'prepared tawriya' presents one or more attributes related to the near meaning - al-muwarrà bi-hi 'the hiding sense' -, which is not intended by the author; 3) Tawriya mubayyana 'explained tawriya' presents one or more attributes related to the distant meaning - al-muwarrà 'an-hu 'the hidden sense' -, which is the one sought by the author; and 4) Tawriya muhayya'a 'prepared tawriya' presents no attribute related to any of the two meanings. However, in this category, the understanding of the tawriyaword is made possible by the presence of another expression - lafz - which discloses it introducing a context, without being a lāzim. As highlighted by Bonebakker $(1966,15)$, an unequivocal definition of läzim's nature is not found in the sources. The only difference which can be pointed out is that the läzim refers to one of the two meanings, but its presence or absence does not affect the understanding of the tawriya-word as such. On the contrary, the presence in the last category of an expression introducing a context through which a second meaning can be understood is essential for the existence of the tawriya. Without it, the tawriya is not recognised as a double entendre, and therefore it does not exist (al-Suyūți 2015, 331)..

After this brief overview, how could we analyse Ibn al-'Ațtār's epigram? The figure tawriya is generally, but not always, based on homonymy (ištirāk). Al-Ṣafadī (2013) defines homonymy as follow:

i'lam anna l-ištirāk 'ibāra 'an lafza mawḍ̂̀'a li-haqiāatayn aw aktar wuḍi 'ā awwal min ḥaytu humā ka-d̄ālika ka-l-'ayn al-maqūla 'alà l-ğāriḥa wa-l-dahab wa-gayri-himā. (101)

stead of isti'māl. We read in Ibn Hiğğa (2001, 3:184) an yaḍkura l-mutakallim lafz mufrad la-hu ma'nayān haqīqiyyān aw haqīqa wa-mağàz ahadu-humā qarīb wa-dalālat al-lafż 'alay-hi zāhira wa-l-ăhar ba'īd wa-dalālat al-lafz 'alay-hi hafiyya fa-yurìdu l-mutakallim al-ma'nà l-ba'ìd wayuwarrì 'an-hu bi-l-ma'nà l-qarīb fa-yatawahhamu l-sāmi' awwal wahla anna-hu yurìdu l-qarìb

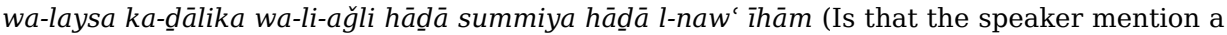
single expression which has two proper meanings or a proper and a figurative, the first of which is near and the denotation of the expression is evident; while the second is distant and the denotation of the expression is hidden. The speaker intends the distant meaning and conceals it with the near meaning; the hearer, instead, supposes at once that the speaker intends the near, but it is not the case. This is why this figure is called suggestion [īhām]). See also al-Nābulusī $(1882,188)$ and the versification by al-Suyūṭi $(2015,324)$.

9 al-Șafadī (2013, 75-81); Ibn Ḥiğğa (2001, 3:533-45; 2011, 268-76); al-Suyūțī (2015, 326-30); al-Nābulusī (1882, 188-97); Bonebakker (1966, 9-23). Ibn Mālik (2001, 252-4) and al-Qazwīnī (2007, 248-50) mention only two types of tawriya: muğarrada and muraššaha. 
Know that homonymy is the utterance of an expression, which has two, or more, proper senses. In this way, a single [expression] is uttered in respect of the two of them [senses], such as 'ayn said about the eye, the gold, and others.

In this epigram the second occurrence of the word 'mūsà' has two proper senses, the first of which being the razor and the latter the name Moses. To understand if the tawriya-word is the central point of the poem, an easy test can be made: the commutation. If the word mūsà is substituted on a paradigmatic level with another word having as referent the near meaning - such as šafra 'razor' - the whole epigram loses its aesthetic value, and turns into an informative utterance, in which a hypothetical customer receives an answer to his question, the answer of which is in accord with common practice within a hammām, i.e. to use a razor to shave his body and pubic hair off. Therefore, the tawriya-word is not a redundant, but rather a fundamental, element without which the literary work is deprived of aesthetic power, i.e. its double reading.

If we turn our attention to the first occurrence of 'mūsà', we see that a tawriya is not intended, for this word can only refer to the name of the bath attendant previously mentioned and not to the razor. Nonetheless, this word is not redundant at all. If we try to substitute it with another, or if we just remove it, the tawriya in the second line would not be understandable. In fact, it would not exist. In my opinion, al-ballānu mūsà in the first line is an example of what Arab literary theorists have called lafz 'expression' and not a läzim 'attribute', which makes the tawriya possible by introducing the context 'hammām' and 'service staff'. This is why, I propose to classify this epigram in the category of tawriya muhayya'a.

Once demonstrated that mūsà is the turning point of this text, the question to be asked is whether the intended meaning is the razor or the bath attendant himself. Al-Lahībī (2014) prefers to interpret the razor as intended meaning, neglecting the possibility for which the intention of the author focuses on the bath attendant, who, in turn, becomes the object of quest. This interpretation is possible because the verb ista'mala can be used and referred to both objects, the razor and the bath attendant. In the first case its meaning is 'to use', like in the sentence 'you use a razor'; in the second case, it acquires an obscene meaning ${ }^{10}$ and the sentence 'you use Mùsà' can be interpreted as a resemantization of the verb entailing an objectification of a person, i.e. the sexual use of the bath attendant. The use of this verb in connection with the tawriya-word is, in my opinion, an example of lāzim referred to the qarīb meaning, since the first sense of the verb ista'mala refers to an object and it is only after a semantic shifting that it acquires an

10 Attested for example in Dozy, Supplément, s.v. " $\mathrm{m}$ l”. 
obscene sense being, thus, referred to a person. In Ibn al-'Ațtāar's epigram both the tawriya-word and the verb are resemantized, i.e. inverting verb meaning and object like in the sentence 'you use Mūsà'. The ambiguity of the whole text is thus generated by the twofold meaning of the tawriyaword, which, together with its verb - the läzim - and the first occurrence of mūsà - the expression (lafz) associated with the tawriya-word -, engenders a double reading of the epigram, the former connected with the usage of a common object for a common practice; the latter with the 'use' of a person, and focusing the attention on (possible) sexual intercourse.

It should be pointed out that the word halwa can be interpreted in a number of ways. When it is found in the context of mystic practice, the sense of 'retirement', 'seclusion' assumes a technical meaning, denoting a period of "isolation in a solitary place or cell". ${ }^{11}$ Certainly, this sense is not compatible with the context of this epigram.

Al-Haymī (1986, 102), commenting on Ibn al-'Atṭār's epigram, provides an explanation of the word halwa based on Islamic law:

wa-fì qawli-hi tasta'milu mūsà mā lā yağrub 'alà al-fațin min kināyat l-nikāya wa-qad qaddama la-hā dikr al-halwa fì l-bayt al-awwal allādī huwa mustawğibu-hu min al-zawğ li-l-zawğa ma'a șiḥhati-hā kamāl almahr 'alà mā qarrara-hu aṣhābu-nā li-l-maḍhab wa-bi-hi qāla Abu Hanīfa raḍiya Allāhu 'an-hu wa-l-imām al-Šāfi '̇̀ 'alay-hi l-salām fì ahad qawlay-hi wa-qad ruwiya fĩ l-qawl al-țānī al-mašhūr 'an-hu bi-anna l-h̆alwa l-șaḥiḥa lā tūğib kamāl al-mahr fa-ntabih ayyuhā l-nabīh li-hādihi l-nikāya allātī ramà l-Šihāb al-'Atțār bi-hā hādā l-ballān wa-rağama-hu bi-hā.

In his utterance "you use mūsà" there is what is not difficult to understand for a perspicacious man as an allusion to the outrage. It is preceded by the mention of the halwa in the first verse, which is the right, when accomplished, of the wife to receive the whole dower from the husband, as it has been established by the authorities of our law school. It has been said by Abū Hanifa (d. 150/767) - may God be pleased with him - and by al-Imām al-Šāfi'ì (d. 204/820) - peace upon him - in one of his two discourses. It has been related, in the second famous discourse, that the halwa l-sahịha does not make mandatory the full payment of the dower. Pay attention, oh noble man, to this outrage with which al-Šihāb al-'Atṭār accuses and reviles this bath attendant.12

This legal sense is related with the consummation of marriage and the involved implications thereof. As a metaphor issued from this sense, the

11 Landolt, H. EI', s.v. "Khalwa”. See also al-Tahānawī 1996, s.v. "ḩalwa”.

12 On the legal meaning of halwa, see al-Mawsū'a l-fiqhiyya 1983, s.v. "halwa". 
word halwa is thus used to mean a lovers' encounter and, more broadly, sexual intercourse as well as homosexual intercourse. ${ }^{13}$

A third very common sense of halwa is 'private room', a room in which one is alone and can there retire for privacy. In the context of a hammām, this private room is an essential part of the architecture itself, which permits the execution of private practice - e.g. pubic shaving - during which no bath attendant should help the customer (al-Munāwī 1987, 36).

One can interpret this ambiguous word as a tawriya too, ${ }^{\mathbf{1 4}}$ in which both senses are possible within the narrative frame of the text. Nonetheless, I prefer to interpret the halwa as the secluded room within the hammäm. The reasons as to why I choose this translation are three. First, I interpret halwa as a space because in this way it enhances the double reading of the tawriya-word, central point of the epigram under analysis, i.e. within a secluded room both shaving and sexual intercourse can happen. Second, I tend to give to halwa the value of a metonymy, expressing the cause in a relation of contiguity with an intended action. For example, it can be understood as the cause for which an action is made possible, i.e. secluded room $>$ shaving and/or intercourse, since both actions are possible within it and not out thereof. ${ }^{15}$ Third, to interpret the halwa as a room does not exclude the innuendo made explicit in the second line of the epigram and it does not hide the sense 'intercourse', which stays in the background and participates to the semantic structure of the whole epigram, as we shall see later.

The complementary interpretation of the halwa as both a secluded room and intercourse raises the issue of how to interpret the question in the first hemistich of the second verse. In fact, if the existence of a private room within a hammām is assumed by any customer, and the background sense of intercourse gives already a hint about one of its possible usages, why should one ask about its purpose? I judge this question a figure of speech, which is itself an example of another figure of speech discussed in

\section{Dozy. Supplément. s.v. "h̆ $l$ w".}

14 In fact, it is not a tawriya, it is a tawğìh. This last figure of speech, accordingly to its last formulation, is based on the use of a word or phrase which has two meanings, one of which is a technical term of art and sciences: Ibn Hiğğa $(2010,2: 353)$ wa-ammā l-tawğīh 'inda l-muta'ahhirīn fa-qad qarrarū an yuwağğiha l-mutakallim ba'ḍa kalāmi-hi aw ğumlata-hu ilà asmā' mutalā'ima știlāh min asmā' a'lām aw qawā'id 'ulūm aw ġayr dôalika mimmā yataša" $a b u$ la-hu min al-funūn tawğìhan muțābiqan li-ma'nà l-lafz al-țānī min ġayr ištirāk haqiàqì bi-ḩiläf al-tawriya (as for the tawğih, later scholars affirmed that the speaker aims, with a part of his utterance or whole discourse, to use some nouns which have also a technical meaning - such as proper names, or scientific principles, or other names among those in which the arts are subdivided - aiming to match the second meaning of the expression [i.e. the ordinary meaning] without being a real homonymy, unlike the tawriya]). See also Bonebakker 1966, 20-2.

15 Al-Ǵuzūlī (1987, 2:316-7) quotes an anecdote about the ḥammām of Šarīf al-Dīn Hārūn b. al-Wazīr al-Ṣāhị Šams al-Dīn Muḥammad b. Muḥammad al-Ğuwaynī (d. 685/1286), in which he enjoyed the pleasure of sex in a special halwa inside his hammām. 
'ilm al-badī': tağāhul al-'ārif 'feigned ignorance'. ${ }^{16}$ This serves to introduce the punning hemistich by providing it with suspense and thus increasing the effect of the tawriya-word. The query uttered in the second line opens to the question of whether the bath attendant is or is not knowledgeable of his possible destiny of 'being used' by a longing customer. From a textual point of view, a univocal interpretation is not possible. The fact that he prepared a room can suggest that he could have been both aware and unaware of this possibility, since setting the room is a part of his duties as an attendant. Moreover, the sexual sense in the background pushes the reader to think that Mūsà prepared a secluded room explicitly for sex, intuition supported by the rhetorical question. This last ambiguity gives the reader the chance to exercise his inferential walks (Eco [1979] 2006). That is to say, starting from the text of the epigram - its fabula -, the reader has the power to imagine and create possible narrative worlds in which his interpretations could be proved or disproved, if only this epigram did not have an open-ended conclusion.

The sexual interpretation of the text leads us to include this epigram in the specific literary genre of muğūn. Bauer provides a categorization of muğūn epigrams in three groups, based on their contents. Ibn al-'Atțār's lines fall under the first category, i.e. "poems in which behaviour of questionable appropriateness is displayed, proclaimed, or reported" (2014a, 162), and more precisely in the sub-category "ostentatious violation of norms" (163).

The reasons for which I have chosen this epigram should now be evident. First, even though it represents only one type of tawriya, it contains all the elements that have been described by Arab theorists as constitutive of this figure of speech. The tawriya-word is a perfect homonym, for its senses are both haqìqa and have two concrete referents. There is a lāzim, ista'mala, related to the qarīb sense, the razor. Moreover, the lafž 'al-ballānu mūsà' in the first line is the expression which makes possible the understanding of the tawriya-word.

16 Al-Sakkākī (2014, 537), Ibn Mālik (2001, 111), al-Qazwīnī (2007, 371-2), Ibn Ḥiǧğa (2010, 2:299-313), Al-Suyūțī (2015, 366-7), Al-Nābulusī (1882, 43-7). This last scholar gives the following definition: tağāhul al-'ārif wa-hādihi l-tasmiya li-bn al-Mu'tazzwa-sammā-hu l-Sakkākī sawq al-ma'lūm masāq ġayri-hi li-nukta wa-qāla lā uhibbu tasmiyata-hu bi-l-tağāhul li-wurūdi-hi fì kalām Allāh ta'ālà wa-huwa an yas'ala l-mutakallim 'an šay' ya'rifu-hu su'āl man lā ya'rifuhu li-yūhima anna šiddat l-šabah al-wāqi' bayna al-mutanāsibayn aḥdațat 'inda-hu ltibās almušabbah bi-hi bi-l-mušabbah wa-fä'idatu-hu l-mubālaġa fi l-ma'nà (The feigned ignorance: this denomination was given by Ibn al-Mu'tazz [d. 296/908]. Al-Sakkākì defined it as "the asking about something known like if it was not for a witty effect". He said: "I do not like the denomination feigned ignorance [tağähul] because it is found in the speech of God almighty". It is that the speaker asks about something that he knows already, as a question made by someone who is not knowing, to make believe that a soundness of similarity found between the two resembling objects produce the confusion between the secundum and the primum comparationis. Its benefit is the emphasis of the meaning). 
Second, Bonebakker underlined that

tawriyas resulting in two equally acceptable interpretations of the sentence (the true double entendre) are of comparatively rare occurrence. The context of the tawriya-word usually creates no more than an association with its second meaning, this association being created occasionally through the fact that one of the meanings, if adopted, would result in a paradox. $(1966,10)$

Ibn al-'Atțār's epigram is an example in which the reading of the text is a perfect double reading, namely in that both meanings of the tawriya-word give a correct interpretation of the text, which is, according to al-Nābulusī $(1882,197)$ also quoted in Bonebakker $(1966,104)$, a requisite for a perfect and successful tawriya. Third, tawriya is not the only ambiguity found in this text. The word halwa is itself ambiguous and connects two meanings with a metonymic relation, enriching the possible interpretations of the muğūn. This is also made possible by a third figure: a rhetorical question connecting the first and the second line, opening the way to the inferential walks of the reader. Finally, the context of the narrative, its narrative world, is deeply rooted in a social institution: the public bath, the hammām. The space itself plays a fundamental role in the understanding of the whole text and in its aesthetic success. It permits, thus, a sociological approach, which takes into account several factors strongly related to the text, but not pertaining to the linguistic level.

Is the analysis thus far illustrated all-encompassing or is there still place for a deeper investigation, which considers other aspects of the epigram in question? In the final page of his work on tawriya, Bonebakker (1966) highlights that

the Arab literary theorists (in addition sometimes to confusing the tawriya with other figures that had little or nothing to do with it) failed to analyze the figure in sufficient detail. In particular they failed to make a distinction between cases where the hearer discovers that the poet is trying to remind him of the two senses of a homonym but has no use for the second sense, and cases where this second sense introduces a surprising new interpretation of the context as a whole. As a result of this the theorists were not completely aware of the artistic possibilities of the tawriya. (105)

In his statement, Bonebakker underlines two key factors which should be considered by scholars dealing with tawriya-poetry: the role of the reader and the importance of the context.

First, when analysing a piece of poetry - and, in general, any text - it is important to remember that each text is created by an author, who, in shap- 
ing his text, takes into account his audience. That is to say that an author takes into account potential expectations and capabilities of hypothetical readers when composing a work, i.e. the Model Reader, as theorised by Eco ([1979] 2006). Taking the role of the reader into account is all the more valuable when considering the aim of poetry, namely its power to communicate, especially in the Mamluk age, as has been pointed out by Bauer (2013a, b).

Second, the study of the figure of speech tawriya in pre-modern literature is not detached from the theoretical tradition of which it is a part: 'ilm al-balāga à 'eloquence, rhetoric'. In fact, in the scholastic tradition, tawriya is classified in the third part of 'ilm al-balāga i.e. 'ilm al-badī' 'figures of speech' among semantic figures: al-muhassināt al-ma'nawiyya. It is true that tawriya has not been first theorised within the scholastic tradition (Bonebakker 1966, 24-43), however, when al-Ṣafadi wrote his treatise - first monograph devoted entirely to tawriya -, the inclusion of bad $^{\prime}$ in the scholastic rhetoric was already established. ${ }^{17}$ As a part of the tripartite rhetoric, figures of speech rely on the general definition of balàga hinged on the requirements of the situation of the enunciation - muqtada l-hâl. ${ }^{18}$ As underlined by Ghersetti (1998), Bauer (2007), and Larcher $(2009,2013)$, the importance devoted to the situation of the enunciation demonstrates the essential pragmatic nature of rhetoric, namely the relevance of the context - maqām - and the audience in the formulation of the utterance. In applying this statement to the work of art - such as, for example, poetry -, we face a twofold value of the context. On the first hand, the external context of enunciation in which a given poem is uttered. On the other hand, the internal context of the poem itself, that is to say its narrative world (Eco [1979] 2006).

In the following sections, I suggest a different approach based on semiotics, which provides a different point of view - among many others possible on the figure under analysis. I do not claim to amend the theoretical system described by Arab literary theorists. Instead, starting from the classical definition of tawriya, I provide a new insight on Ibn al-'Ațtār's epigram, which is meant to shed light on the role of two fundamental components responsible for aesthetic value: the role of the reader and the contexts of the enunciation and narrative. In doing so, I propose a method of investigation which can prove to be rewarding when applied to other tawriya-texts, in both poetry and prose. As easy as it may seem, we should not fall into the trap of considering this epigram as a simple joke, and consequently underestimate its narrative complexity. Having said that, a similarity between this epigram and a joke can be detected, and the Isotopy-Disjunction Model is informative in attempting to understand this entwinement.

17 Al-Sakkākī 2014; Ibn Mālik 2001; al-Qazwīnī 2007; Bonebakker 1966, 44-62.

18 Al-Sakkākī 2014, 250; Ibn Mālik 2001, 99; al-Qazwīnī 2007, 16. 


\section{The Isotopy-Disjunction Model}

Humour, word plays, puns, and jokes have been a theme of discussion and analysis since the Ancient Greeks, e.g. Plato and Aristotle. Many scholars have attempted to define the principles of textual humour from different viewpoints. Ibn al-'Atțār's epigram presents several features in common with jokes and word plays, which allow us to draw a parallel between the structures of these two textual types: the joke and the epigram. In order to better understand this parallel and sketch the internal structure of the epigram, I employ a theoretical system first drawn during the 1960s after the essays by Greimas (1966) and Morin ([1966] 1981), which prove rewarding in the analysis of different forms of humorous texts: The IsotopyDisjunction Model. This designation is owed to Attardo (1989; 1994), who underlines two key factors of this method of analysis: first, the notion of Isotopy, used first by Greimas (1966), which had several reformulations during the following decades. Second, Morin's disjunction model, which provides us with a first description of jokes structure.

As underlined by Attardo (1994) and Aljared (2017), the concept of isotopy, first formulated in Greimas (1966), has been rethought several times and many scholars applied it in the analysis of texts. In Greimas and Courtés $(1982,163)$, we read: "as an operational concept, isotopy at first designated iterativity along a syntagmatic chain of classemes which assure the homogeneity of the utterance-discourse". Classemes are contextual semes - i.e. meaning unities which set a particular context of the text - which guarantee a uniform reading of the text by their repetition. Classemes are what Eco ([1979] 2006) calls contextual selections distinct from circumstantial selections:

una selezione contestuale pertanto registra i casi generali in cui un dato termine potrebbe occorrere in concomitanza (e quindi co-occorrere) con altri termini appartenenti allo stesso sistema semiotico. Quando poi il termine concretamente co-occorre con altri termini (quando cioè la selezione contestuale si attualizza) ecco che abbiamo un co-testo. Le selezioni contestuali prevedono dei possibili contesti: quando si realizzano si realizzano in un co-testo.

Quanto alle selezioni circostanziali esse rappresentano la possibilità astratta (registrata dal codice) che un dato termine appaia in connessione con circostanze di enunciazione. (17)

A contextual selection, therefore, records the general cases in which a given term may occur concurrently (and therefore co-occur) with other terms belonging to the same semiotic system. When the term concretely co-occurs with other terms (when the contextual selection is actualised), we have a co-text. Contextual selections foresee possible contexts: when they are realized they are in a co-text. 
As for the circumstantial selections, they represent the abstract possibility (recorded by the code) that a given term appears in connection with enunciation circumstances.

Therefore, the co-text - i.e. the actualisation in the linear dimension of the text of a given set of terms pertaining to a specific context - plays a crucial role in the reading coherence of a text. This coherence is what is meant with isotopy, namely "coerenza di un percorso di lettura" (93) (coherence of a reading path), in Eco's ([1979] 2006) words. ${ }^{19}$ In the epigram under analysis, the main isotopy is introduced in the first verse, in which two words - ballān and halwa - are uttered. They pertain to the abstract context 'hammām' and create a coherent co-text determining a sound reading, permitting to the reader to infer a certain 'state of affairs' in which rules and expectations are stereotyped. This is the concept of frame:

when one encounters a new situation (or makes a substantial change in one's view of the present problem) one selects from memory a structure called a Frame. This is a remembered framework to be adapted to fit reality by changing details as necessary. A frame is a data-structure for representing a stereotyped situation, like being in a certain kind of living room, or going to a child's birthday party. Attached to each frame are several kinds of information. Some of this information is about how to use the frame. Some is about what one can expect to happen next. Some is about what to do if these expectations are not confirmed. (Minsky 1974)

By setting the frame 'hammām', the author wants his reader to frame his reading in a given context in which rules of decode apply. For example, the reader is brought to interpret the linear sequence in the first verse as a description of common practice in a public bath: a bath attendant preparing a private room for a customer. To this extent, the term halwa is in my opinion to be interpreted as 'secluded room', instead of 'private encounter', 'intercourse', being, however, both senses in the background of the narrative. The first isotopy is 'broken' in the second line, at the end of which the homonym word mūsà is uttered. This leads us to a second isotopy depending from the previous: sexual encounter. By the enunciation of the tawriya-word, a different reading strategy should be adopted, i.e. being the frame of the narrative a public bath, its rules have been, in a certain way, changed, and unexpected actions and practice are intro-

19 For an overview of the different phases of conceptualization of the term isotopy and its application to word plays, see Attardo (1994, 60-85) and Aljared (2017, 64-6). To my knowledge, Aljared is the first scholar who applied the Isotopy-Disjunction Model to jokes in classical Arabic in her Master Dissertation, which unfortunately I could not consult. Some of her findings are provided in Aljared 2017. 
duced in the narrative world. This is due to the fact that the interpretations mūsà-razor and mūsà-bath attendant have two different contextual selections, for one can use a razor in a hammām to shave himself but should not 'use' the attendant for his sexual pleasure. At a closer look we notice that the two isotopies - public bath practice and sexual encounter - are coexistent, they are not mutually exclusive, for they enrich the meaning of the text permitting a double reading thereof. In Eco's words they are "isotopie narrative non vincolate a disgiunzioni isotopiche discorsive che generano in ogni caso storie complementari" ([1979] 2006, 100) (narrative isotopies not bound to discursive isotopic disjunctions, which generate either way complementary stories), namely "la permanenza di un'unica coerenza discorsiva fa sì che in questo caso le due isotopie narrative non si annullino a vicenda, non siano in rapporto di esclusione o alternatività, ma di complementarietà [Author's italics]" (100) (the permanence of a single discursive coherence means that, in this case, the two narrative isotopies do not cancel each other out, they are not in a relationship of exclusion or alternativeness, but of complementarity).

How can we describe this isotopy change from a syntactic and semantic viewpoint, allowing us to understand the inner structure of the epigram under analysis?

In an article published in 1966, Morin analyses some jokes, or histoires drôles, published in the newspaper France-Soir, throughout a six-month period. Her aim was to demonstrate that a joke, as easy and short it may seem, is to be considered a récit 'narrative', composed by "une séquence unique qui pose, argumente, et dénoue une certaine problématique" ([1966] 1981, 108) (a unique sequence that poses, argues and resolves a given problem). Moreover, Morin's investigation examines the functions in which the narrative is articulated, and enumerates them as follow:

une fonction de normalisation qui met en situation les personnages; une fonction locutrice d'enclenchement, avec ou sans locuteur, qui pose le problème à résoudre, ou questionne; enfin une fonction interlocutrice de disjonction, avec ou sans interlocuteur, qui dénoue 'drôlement' le problème, qui répond 'drôlement' à la question. (Morin [1966] 1981, 108)

a normalisation function, which puts the characters in a situation; an interlocking function, with or without a speaker, which poses the problem to be solved, or questions; finally, a function of disjunction, with or without interlocutor, which solves the problem humorously, which answers humorously to the question.

When applying these functions to Ibn al-'Atțār's epigram, we obtain the following scheme: 
1. The normalisation function develops in the first verse:

Hayya'a l-ballānu Mūsà halwatan tuhyī l-nufūsa

The bath attendant Mūsà prepared a secluded place, which revives the souls.

2. The interlocking function develops in the first hemistich of the second verse:

Qultu mā așna'u fi-hā? I said: "What should I do in it?"

3. Finally, the function of disjunction develops in the last hemistich, with the presence of the 'disjunctor':

Qāla tasta'milu mūsà He replied: "You use a Mūsà/razor!"

It is by this last function, that the narrative acquires its characteristic of ambiguity, in which both serious and humorous are present. This is possible thanks to a polysemous term: the disjunctor. Based on the nature of the disjunctor-element, Morin classifies two types of texts: the first is the text in which the disjunctor-element is a sign - disjonction sémantique 'semantic disjunction' in Morin's words (109) -, namely its efficacy is to be ascribed to the semantic level of the disjunctor-sign itself. The second disjunctor-element, on the other hand, is a referent to which signs refer - disjonction référentielle 'referential disjunction' (109).

From this point of view, Ibn al-'Atțār's epigram is similar to what Morin describes, since it shows a unique narrative sequence, by which a narrative is articulated. The disjunctor is the tawriya: the word mūsà, which indicates both the bath attendant and a razor, and allows us to categorise the epigram as "récit a disjonction sémantique" (109) (narrative with a semantic disjunction). The word mūsà is thus a homonym, which in turn refers to two referents, engendering a double reading of the text, one related to the previously mentioned bath attendant, and the other to the bath tool razor. This is why I adopt Morin's definition of "articulation régressive par homonymie de signifiants" (115) (regressive articulation by homonymy of signifiers).

However, speaking about a mere double reading of the text can be misleading. Morin underlines that these types of narrative present a formal coherence, which is regarded in the two first functions. It is only in the last function, after the enunciation of the tawriya-word, that a turn takes place, which leads to a different comprehension of the text, or, better, to two different yet mutually reliant texts. The reason is because mūsà in the last verse alludes to Mùsà in the first, connecting the last function to its precedents, forcing the reader to backtrack on a circular way. Morin (116) affirms that we are in front of two texts, one 'normal' - which I call primary $-\left(T_{1}\right)$ and another 'parasite' $\left(T_{2}\right)$, the source of the parasite text being the disjunctor, as in the following scheme: 
Primary text

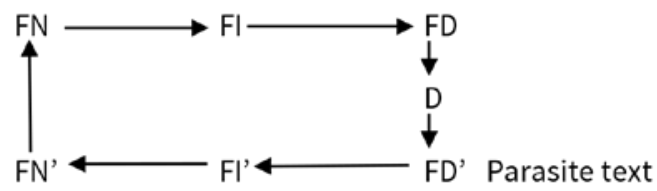

FN: normalisation

$\mathrm{Fl}$ : interlocking

FD: disjunction

D: disjunctor

Figure 1. Morin [1966] 1981, 116

We are facing two texts: $T_{1}$ has as normalisation function the informative utterance expressed in the first line, which informs us about the existence of a secluded place within the hammām, specifically set up by the bath attendant named Mūsà, followed by the interlocking function, which questions the purpose for which the secluded room has been prepared, and ending with the function of disjunction, by which the disjunctor mūsà places us before a fork in the road: one leading us to the conclusion of $\mathrm{T}_{1}$, if we understand mūsà as a razor; the other to $\mathrm{T}_{2}$, in which Müsà is the bath attendant himself. In this case, 'use Mūsà' is to be interpreted as a sexual use, and therefore as sexual intercourse with the bath attendant. The interpretation of the last function - disjunction - relies upon the understanding of the previous function - interlocking - as a rhetorical question, asked after the information expressed in the first verse by the normalisation function, based on the assumption that the secluded room has been prepared by Mūsà for a specific and precise purpose, which should be already known by a possible customer.

But, how can a single text become two interdependent texts? The disjunctor-tawriya is not the only source of this duplication, for another fundamental element linked to the tawriya-word is involved. As stated above, the element which 'helps' the tawriya in its working is the verb ista 'mala, which in my opinion alludes to al-muwarrà bi-hi if we consider its common sense - use a razor -, and to the al-muwarrà 'an-hu if we adopt its obscene derivation. Indeed, I interpret mūsà-razor as the near meaning, since this referent is a common bath tool, and one expects to use it while having being in a hammām. Even the referred verb does not imply any resemantization. On the other hand, if the referent is Mùsà-bath attendant, we face a resemantization of the phrase 'tast'milu Mūsà', which brings us to the bath attendant uttered in the first verse and changes the meaning of the phrase conveyed to the reader to a 'sexual use of Mùsà', which is the meaning sought by the author, contrary to al-Lahībī's (2014) opinion.

Once again, Morin's analysis is comparable to our tawriya-epigram. In her article, she mentions the function executed by a word, which she calls adjuvant, as having the function to transfer the disjunctor from a text to the other: 
le disjunctor est transféré d'un récit à l'autre avec l'élément qui le fonctionnalise [...] cet adjuvant fonctionnel consolide la rigueur du formalisme et rend par-là plus éclatante, parce que plus signifiante, la coïncidence disjonctante. (Morin [1966] 1981, 117)

the disjunctor is transferred from one narrative to another with the element which functionalises it [...] this functional adjuvant consolidates the formalism rigour and thus makes the disjunctive coincidence more striking, for it becomes more meaningful.

Morin's adjuvant is the Arabic läzim; thanks to it, two texts develop in interdependency. This is possible for two reasons. First, the verb is a strong adjuvant with a high power of resemantization; second, it alludes to a referent already mentioned, i.e. a human who is not supposed to be 'used' - uttered in the first line and constitutive element for the existence of the tawriya.

As we have seen thus far, this epigram is a complex structure. If at first sight it seems to be a single text, this enquiry has revealed that, in fact, we are facing two texts interdependent of each other, the second a parasite of the first, which, in turn, gains legitimation from its parasite. However, what I have presented so far does not cover fully the potential of analysis of this epigram. Since it is a text - a narrative, a récit -, it also possesses a narrative schema, which I outline in the next section.

\section{The Narrative Schema}

Every text presents a common schema, with which the actions of several 'actors' can be described. In its essence, this epigram is a dialogue, in which an Interlocutor and an Interlocutee act, and where we can recognise an uttered enunciation, which is

only the simulacrum within the discourse imitative of the enunciative doing: the ' $\mathrm{I}$ ', 'here', and 'now' that we encountered in uttered discourse in no way represents the subject, space, or time of the enunciation [Author's italics]. (Greimas, Courtés 1982, 105)

The enunciation is the place within which the instance of the subject of the enunciation takes place, an original act, which produces an utterance. The enunciation itself starts with a fundamental act, which puts into the play the categories of ego, hic et nunc, called disengagement. In this view of the enunciation, we can distinguish two types of disengagement: enunciative disengagement and utterative disengagement, the former of which is found in dialogic sequences between an Interlocutor and an Interlocutee. 
As underlined by Greimas and Courtés (1982), they are not to be considered as the real subjects or actors of the speech act, of the enunciation, but rather actants thereof:

an actant can be thought of as that which accomplishes or undergoes an act, independently of all other determinations. [...] From this point of view, 'actant' designates a type of syntactic unit, properly formal in character, which precedes any semantic and/or ideological investment. (Greimas, Courtés 1982, 5)

They are abstract elements which stand for a specific function and 'perform' a narrative program, i.e.:

an elementary syntagm of the surface narrative syntax, composed of an utterance of doing governing an utterance of state. [...] The narrative program is to be interpreted as a change of state effected by any subject (S1) affecting any subject (S2). (Greimas, Courtés 1982, 245)

The narrative program is thus the elementary element which describes a function. In a text we can recognise at least two actants: the Subject and the Object, the two of which can be in a relation of conjunction or disjunction. The narrative program's description of the Subject acquiring the Object of quest is thus called performance.

Let us turn our attention to the first verse: "The bath attendant Mùsà prepared a secluded place, which revives the souls". The dialogic sequence starts with a first enunciative disengagement, with which the Interlocutor addresses his Interlocutee. In this verse we can recognise a fundamental actant figure, the Addresser, namely who is going to provide his AddresseeSubject with the modal competence. In particular, the modal competence provided is the knowing-being-able-to-do, actualising modal competence, expressed in the first line with the informative utterance, which informs about the presence of a secluded place, within which a performance can take place, that is to say the conjunction with the Object of value, which is made explicit, in its twofold nature, only in the second verse. At the same time, the first verse is also the place of a virtualising modality, instilling in the Subject the wanting-to-do, earlier unknown and unexperienced. This line is thus the bearer of two distinct modalities, which introduce the possibility of a final performance.

Proceeding to the first hemistich of the second line - "I said: 'What should I do in it?'” -, we are faced with a second uttered enunciation containing the first internal enunciative disengagement, in which the instance of the Subject, here the Interlocutee-Addressee-Subject, is revealed by the use of a verbal form in the singular first person. The question posed by the Subject is nothing, but the expression of the modality wanting-to-know. 
Having received the information by the Interlocutor-Addresser about the presence of a secluded place, in which a performance is possible, and having acquired the first actualising competence of being-able-to-do, and its resulting virtualising competence of wanting-to-do, he needs now to acquire the actualising modal competence of knowing-what-being-ableto-do and he can achieve it using the virtualising modality of wanting-toknow-what-being-able-to-do, expressed by the question.

A very last internal enunciative disengagement can be detected in the second hemistich of the second verse: the Interlocutor-Addresser replies to the question of his Interlocutee-Addressee-Subject giving him the information he needed to obtain his knowing-what-being-able-to-do, revealing finally the nature of the Object of quest: mūsà.

At this stage we can identify the base narrative program, in which the Subject is disjointed from the Object mūsà, making us face an ambiguity of values. According to the interpretation given to the tawriya, the value attributed to the Object can be 'to shave', or 'to use the bath attendant', i.e. to have sexual intercourse with him. The instrumental narrative program - namely the narrative program by which the Subject acquires the necessary modalities in order to reach the conjunction with his Object of value - is to be found in the first line and in the second hemistich of the last verse, by which the Interlocutor-Addresser confers the modalities of knowing and being-able to the Subject, since it is the presence of a secluded place that makes the performance possible. At the same time, the Interlocutor-Addresser, by informing his Interlocutee-Addressee-Subject, instils him with the modality wanting. Once these modalities have been provided, and the Object made explicit, we can talk about manipulation, cognitive dimension, from the Interlocutor-Addresser towards his Interlocutee-Addressee-Subject, in becoming the Interlocutor-Addresser-Manipulator. This manipulation allows the stipulation of a fiduciary contract whereby the Object of value will be acquired, under certain conditions.

However, the Object is still unknown to us, or better, we are facing two possible Objects of value, the first being the razor, and the second the attendant. It is up to the Subject, as disjointed of the Object, to give it a value, according to his scale of values, choosing if he leaves the hammäm shaved or sexually satisfied or, maybe, both as the double reading of the epigram could suggest. Another point to which I would like to draw attention is the figure of the bath attendant Mùsà, quoted in the first line, who plays an actantial role too. If the Object is recognised as a razor, Mūsà represents the actant Helper, i.e. the actantial figure who helps the Subject to achieve his narrative program, arranging a suitable place to perform the performance. On the contrary, if the Object is recognised as the sexual intercourse with the attendant, then Mùsà is both the Helper and the Object itself.

We have so far recognised in this text the first two moments of the canonical narrative schema: the first, the manipulation, occurs from the side of 
the Addresser towards his Addressee, permitting him to acquire the competence, second moment of the narrative schema. Nevertheless, the text is still suspended, since the performance - the third step of the schema - has not yet been realised, for we do not know for certain what the Object or the values thereof are, nor do we know if at the end the Subject is going to be joined with or disjointed from it. Thus, we have suspense. Since the performance does not take place, the last component of the schema, the sanction by which the Addresser sanctions positively or negatively the performance of the Subject, is also not realised. At this level the text is open, and it is up to the reader to complete it. Firstly, given a twofold Object, the reader has the possibility to make a decision grounded on his own encyclopaedia (Eco [1979] 2006), choosing if the value to be attributed to the Object is 'shaving' or 'sexual intercourse' or both. On the basis of this decision he is going to sanction, positively or negatively, the hypothetical performance. I must here underline that the value of the Object is not established at the level of textual actants: neither the Addresser nor the Addressee have the power to decide for this is the prerogative of the reader alone. He can complete the text, cooperating, in fact, with its writing and conclusion. This is the pivotal point of this epigram. The presence of the tawriya involves the reader in the narrative process, asking for a personal commitment in order to accomplish it, following the traces left by the author who, having chosen as place of the narration a hammām and using an erotic double entendre, relies on social norms and shared knowledge, which I shall relate in the following pages.

\section{Applying the Semiotic Square}

The tawriya, with its charge of ambiguity, opens the interpretation of the text. But how can we understand the aesthetic pleasure ascribed to this epigram? In other words, why is it that reading, or listening, to these verses provokes pleasure? We can identify the answer to these questions if we consider the semiotic square.

In the following investigation I borrow the words of Marrone (2001), who suggests an analysis of the narrative of communications based on the semiotic square, as in this scheme:

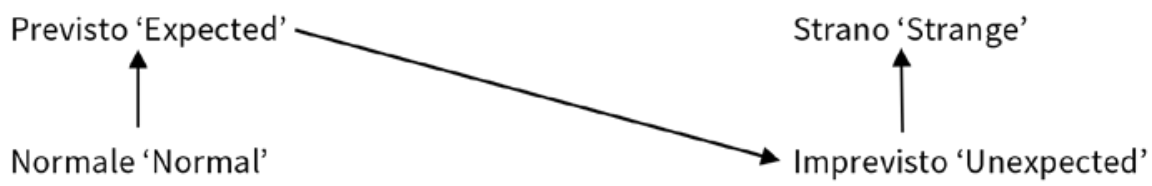

Figure 2. Marrone 2001, 95 
The interpretation of this scheme is as follows: the normal entails the expected, which is the negation of the unexpected, which entails the strange. The normal is implied and it is from what is perceived as normal that we can understand why the 'making headlines' of an event considered strange is in fact a normal reaction because of its break from expectation.

We can apply this scheme to our epigram in order to understand the effect of estrangement caused by the tawriya. The first line takes us inside a hammām, where the presence of one or more attendants helping customers is to be considered 'typical'. The presence of a secluded, intimate, place, away from prying eyes, within which the full nude and private practice, such as the intimate shaving, are permitted, is common. In this regard, it can be affirmed that the narration contained in the first line describes a 'normal' environment, since the mentioned people and places are 'expected'. However, the question in the second verse, addressed by the Interlocutee to the Interlocutor, draws and transfers our attention from an 'expected' scenario towards a hypothetical 'unexpected' behaviour, eliciting a doubt contrary to the common expectations: why should one ask about possible actions to be performed within a secluded place, when the existence of the room itself should not arouse any doubt? What is its function?

The answer at the end of the second line is ambiguous. Since the razor is an 'expected' tool, and the act of shaving a common practice in a hammām, the interpretation of the word mūsà as razor does not lead to the 'unexpected' and keeps the text in a 'normal' scenario. On the other hand, if we interpret the word müsà as the name of the attendant, we notice how the change of the referent leads us to a shift from the 'normal' to the 'strange', the latter of which being sexual intercourse. This is all the more so the case given that within a hammām intercourse is forbidden, not to mention male-male intercourse with the attendant himself. ${ }^{20}$

To better understand how this shifting occurs, I resort to the essay by Greimas and Rastier (1968) describing the system of sexual relations. Considering their example, I draw the scheme of sexual relations, based on the permitted and unacceptable relations according to the social model, as follow:

20 About the prohibition of sexual promiscuity and sexual intercourse see Benkheira 2007, 2008; van Gelder 2008; al-Haymī 1986, al-Munāwī 1987, and the next section of this article. 
Licit relations

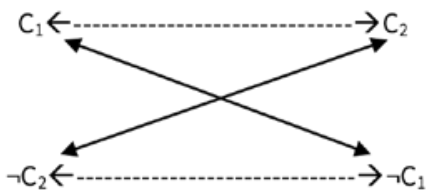

Not forbidden relations
Forbidden relations

Not licit relations

Figure 3. Greimas, Rastier 1968, 93

The relations between $\mathrm{C}_{1}$ (licit relations) and $\mathrm{C}_{2}$ (forbidden relations) and between $\neg C_{1}$ (not forbidden relations) and $\neg C_{2}$ (not licit relations) create contrariety, and that between $C_{1}$ (licit relations) and $\neg C_{1}$ (not licit relations) and between $C_{2}$ (forbidden relations) and $\neg C_{2}$ (not forbidden relations) contradiction. Thus, $C_{1}$ (licit relations) and $\neg C_{2}$ (not forbidden relations) are permitted relations, while $C_{2}$ (forbidden relations) and $\neg C_{1}$ (not licit relations) are unacceptable.

I then borrow the following scheme to consider the model of individual values:

Desired relations

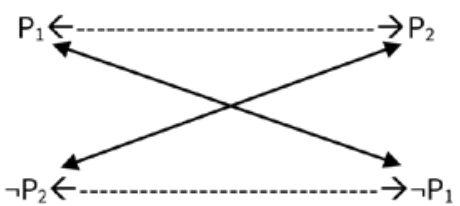

Not feared relations

Not desired relations

Figure 4. Greimas, Rastier 1968, 96

The relations between $\mathrm{P}_{1}$ (desired relations) and $\mathrm{P}_{2}$ (feared relations) and between $\neg \mathrm{P}_{1}$ (not desired relations) and $\neg \mathrm{P}_{2}$ (not feared relations) create contrariety, and that between $\mathrm{P}_{1}$ (desired relations) and $\neg \mathrm{P}_{1}$ (not desired relations) and between $\mathrm{P}_{2}$ (feared relations) and $\neg \mathrm{P}_{2}$ (not feared relations) contradiction. $\mathrm{P}_{1}$ (desired relations) and $\neg \mathrm{P}_{2}$ (not feared relations) are permitted relations, while $P_{2}$ (feared relations) and $\neg P_{1}$ (not desired relations) are unacceptable. The next step is to assign actions and states to the terms of the square.

Let us consider $\mathrm{T}_{1}$ : from a social point of view, the action of shaving with a razor and depilatory paste in a hammām is permitted, if not recom- 
mended, and therefore it is a licit action that has its room in the semiotic square as $\mathrm{C}_{1}$ (licit relation). On the level of individual values, the act of shaving can be considered a desired action, and the place $\mathrm{P}_{1}$ (desired relation) can be assigned to it. Thus, if the relation is $\mathrm{C}_{1}+\mathrm{P}_{1}$, namely a prescription (licit relation) plus another prescription (desired relation), we are facing a balanced relation since it is a "relation between homologous terms" (Greimas, Rastier 1968, 97).

On the other hand, actions and states of $\mathrm{T}_{2}$ have to be considered accordingly with the notion of male homosexuality. From a social point of view, male homosexuality can be placed in more than a place of the semiotic square. For example, it is considered to be forbidden $\left(\mathrm{C}_{2}\right)$ being contrary to recognised norms, especially when occurring between two adult men since, as Bauer (2014b) points out, it is in opposition with the received idea of masculinity; nonetheless it can also be considered as not forbidden $\left(\neg C_{2}\right)$ in the case that the intercourse occurs between two men, one of whom is not considered an adult yet - e.g. who has not yet a full-grown beard -, thus falling under the place of permitted relations. However, if we consider the place in which the action takes place, a hammām, we face a repositioning of the action to the level of the not licit relations $\left(\neg C_{1}\right)$, even if Mùsà is an adolescent. This has to be ascribed to the fact that coitus is strictly forbidden within a hammām regardless of the sex of the lovers.

Here, I must highlight that in this analysis I am referring to a specific social context, in which poetry addressed to beautiful young was a widespread genre, and in which homoerotic muğūn-poetry often depicted malemale sexual intercourse. Szombathy (2013) clearly specifies the difference between norms and real behaviour:

the norm could not be clearer: homoerotic lust is dangerous and must never be indulged; sodomy is an abomination, a sin and a crime. Anal sexual congress between two persons of the same sex is under all circumstances illicit and subject to punishment. This was the unanimous opinion of all Muslim jurists, which also correspond to the popular assessment of the phenomena. [...] Homosexual sex - especially with slave-boys and other low-status youngsters - was widely available in Middle Eastern cities, nor was it uncommon for men to try to seduce adolescents or buy and keep slave-boys for sexual gratification. (9-10)

The fact the real behaviour could have been contrary to the recognised norm is not a sufficient statement to prove the lawfulness of this practice. Accordingly to Szombathy $(2013,138)$, muğūn-texts "were clearly designed to be as provocative as possible, [...] the theme of homosexuality was chosen and elaborated for its shock value, out of a simple Effekthascherei". Nonetheless, it is true that "medieval Muslims, like members of many other societies, viewed the act of penetrating a man as a sin, but a sin that did not lessen the 
virility of the active partner, while it all but destroyed the honour of whoever played the passive role" (135). This is why I have assigned to intercourse the position $\mathrm{C}_{2}$ (forbidden relation), in respect to the violation of recognised norms; and $\neg C_{2}$ (not forbidden relation) in consideration of the social reception which sees Mūsà as an adolescent. It is not a full licit relation $\left(C_{1}\right)$, but a kind of relation - expressed in a given literary genre - that could be accepted under certain conditions - e.g. with a young bottom slave - not damaging the virility of the active partner, although being a sinful practice, contrary to the recognised norm. However, as stated above, the place in which the action takes place brings us to consider the relation as a not licit relation $\left(\neg \mathrm{C}_{1}\right)$, even if Mūsà is an adolescent.

From the point of view of individual values, I will at first assign to the will of a sexual intercourse with Mùsà the place of a desired relation $\left(\mathrm{P}_{1}\right)$, but it can also be considered at least as a not feared sexual relation $\left(\neg P_{2}\right)$.

Let us now verify the structure of the relations described so far: assuming the normative viewpoint, I consider as invariant the forbidden social relation $\left(\mathrm{C}_{2}\right)$, and as variant the desired relation $\left(\mathrm{P}_{1}\right)$ and the not feared relation $\left(\neg \mathrm{P}_{2}\right)$.

If the relation is $\left(\mathrm{C}_{2}+\mathrm{P}_{1}\right)$, namely an interdiction (forbidden relation) plus a prescription (desired relation), the result is a conflictual relation, that is to say that we are facing a conflictual relation between two contrary terms, which creates a strong conflict. If the relation is $\left(C_{2}+\neg P_{2}\right)$, namely an interdiction (forbidden relation) plus a non-interdiction (not feared relation), we are facing once again a conflictual relation, but in this case between two contradictory terms, which poses a less serious conflict. The relation depicted in the opposition of two contraries represents the will to make a prohibited wish - which is not accepted from a normative point of view - to come true. Thus, it represents a form of deviance. On the other hand, the relation depicted in the opposition of two contradictories - opposing an interdiction to a non-interdiction - describes a state which is weaker than the opposition of contraries. Thus, it represents a transgression. In both cases there is a primacy of the individual to the normative. ${ }^{\mathbf{2 1}}$

To review what we have seen so far, we have two texts: $T_{1}$, when it is applied to the semiotic square, shows us a narration which does not exceed the bounds of the common expectations, it reaffirms them. On the other

21 What about if we consider intercourse from a 'social' point of view? The result does not wander from the given analysis, since we need to consider the role played by the place in which the action takes place. Considering as invariant the not licit social relation $\neg \mathrm{C}_{1}$, and as variant the desired relation $\mathrm{P}_{1}$ and the not feared relation $\neg \mathrm{P}_{2}$, the result of the combinations is as follow: $\neg \mathrm{C}_{1}+\mathrm{P}_{1}$ and $\neg \mathrm{C}_{1}+\neg \mathrm{P}_{2}$. If we consider the first combination, namely a non-prescription (not licit action) plus a prescription (desired action), we are facing a conflictual relation, since they are two contradictory terms on the basis of the contradiction of prescription. The second combination is a union of a non-prescription (not licit action) plus a non-interdiction (not feared action), and thus it is a conflictual relation between two contrary terms, weaker than $\mathrm{C}_{2}+\mathrm{P}_{1}$ above mentioned. 
hand, $\mathrm{T}_{2}$ turns over the common expectations, taking the reader towards the unexpected, within which the tawriya can engender aesthetic pleasure. To understand the unexpected perceived by the reader, we need to pay attention to the non-performed performance and interpret it in view of the social relations expressed through the semiotic square. In doing so, it can be affirmed that the unexpected is engendered by the deviance or by the transgression, which go beyond the norm.

Nonetheless, the use of the semiotic square has shown that in order to assign actions and states to the correct position within the square, we have to consider another instance, which only superficially could be considered as an outside and insignificant element of the narrative: the place in which the action takes place.

\section{Space as a Text}

I have already demonstrated how this epigram contains in fact two texts. Now, I wish to draw the attention to what I call the third text, already mentioned, but not considered in its importance yet: the space, the hammām.

To speak about a hammām in pre-modern Arabic society is to open a trunk full of meanings. To retrace the history of this institution is not the aim of this contribution, this is why I limit myself to underline a few aspects, which are essential for the analysis of the epigram. ${ }^{22}$ Benkheira (2007, 2008) underlines the fact that the hot bath existed before the advent of Islam. The Roman and Byzantine habits were embraced by the Arabs. However, Islam posed several questions about the lawfulness of this practice. First of all, within a hammām it was prohibited to pronounce the name of God and recite the Quran. Promiscuity between sexes had been forbidden, as well as full nudity (al-Munāwī 1987, al-Haymī 1986). Benkheira (2007) stresses how this prohibition dates to the beginning of Islam, quoting several Prophet's traditions - although controversial - and also traditions and orders ascribed to the caliphs 'Umar (d. 23/644) and 'Alì (d. 40/661). In general, the frequentation of hammām was a practice accepted by jurists, since the benefits of a hot bath were recognised from several points of view: religious, for it makes possible the ritual purity; therapeutic, since its benefits were recognised in case of illness, ${ }^{23}$ to the extent to which even women could frequent the hammām; and recreational, giving space for amusement

22 The birth, development, and (near) death of the hammām have caused rivers of ink to flow. It is not possible within the limits of this article to consider all these aspects, and I refer to the bibliography given at the end.

23 About therapeutic aspects of the hammām see al-Munāwī 1987, Koetschet 2014 and Denoix 2014. 
and public relations. ${ }^{24}$ Nonetheless, the promiscuity between customers, even if they were wearing a loincloth, was seen as a potential temptation towards 'homosexuality', in particular among youths. In this regard Benkheira quotes an anecdote ascribed to Sufyān al-Tawrī (d. 161/777-8):

un jour que Sufyān Tawrī était au ḥammām, un jeune garçon, au beau visage, pénétra. Sufyān s'écria: “Ôtez-le de ma vue!” On fit sortir le bel enfant. Le grand juriste de Kūfa expliqua : "Si chaque femme est accompagnée d'un démon, chaque jeune garçon l'est par dix démons!". (Benkheira 2007, 364)

One day, when Sufyān Tawrī was in a hammam, a young boy with a beautiful face entered. Sufyān exclaimed, "Take him out of my sight!" The beautiful boy was taken out. The great jurist of Küfa explained: "If every woman is accompanied by a demon, every young boy is accompanied by ten demons!".

Shaving, with the help of a depilatory paste called nūra (al-Haymī 1986, 4853; al-Munāwī 1987), obtained the consensus of (almost) every authority, both, religious and political: "une des raisons pour lesquelles le hammām a été adopté par les musulmans et accepté par la majeure partie des oulémas est que l'on s'y épile, notamment le pubis" (Benkheira 2007, 363) (one of the reasons as to why the hammäm has been adopted by Muslims, and accepted by most of the jurists, is because one shaves himself off, especially the pubis) (Grotzfeld 1970, 75-7). To support this affirmation, Benkheira quotes several sources, among them jurists and caliphs. ${ }^{25}$ What I have summarised so far describes the received view about permitted and prohibited hammām practice. Later sources - Mamluk and Ottoman - do not introduce any remarkable change to this 'dos and don'ts' framework, as can be seen, for example, in al-Haymī (1986).

After these preliminary remarks, a question arises. How does the conception of how one uses a hammām play into the understanding of this epigram?

Let us consider first a classification of spaces. Marrone (2001) lists and describes different spaces as pre-ordered, semi-determined and informal.

24 “L'historiographie confirme nettement cette conclusion. Prétendre que les musulmans n’ont adopté le bain public que parce qu'il leur permettait de satisfaire aux rites de la purification est une méprise évidente. Or c'est à peu près pour les même raisons que les Romains et ensuite les Byzantins fréquentaient les thermes" (Benkheira 2007, 327) (Historiography confirms clearly this conclusion: to claim that the Muslims adopted the public bath only because it allowed them to satisfy the rites of purification is an obvious mistake. But it is about the same reasons that the Romans and then the Byzantines frequented the public baths).

25 For an in-depth discussion about sources, see the bibliography, in particular Benkheira 2007, 2008 and Melchert 2014. 
The first type of spaces is set in view of a particular usage, at which the user is supposed to comply; the second type allows to the user a semifreedom, allowing a resemantization of the space depending on his wishes; the last type is supposed to be flexible, apparently set without any rule, allowing a complete freedom to the user. Considering these typologies, I propose to consider the hammām between a pre-ordered and a semidetermined space, namely a place built for precise usage, but at the same time subject to resemantization by its user. David and Mounif (2014), speaking about the hot baths in Aleppo, underline how the hammām has to be considered a path accompanying the customer from the first and external part of the building to the inner part. ${ }^{26}$ If we adopt the Syrian terminology, we define the first cold room barrānī, usually the biggest room, in which customers undress themselves before entering the hot rooms, as well as relax themselves at the end of the bath experience. Following the path outside $>$ inside/cold $>$ hot, the second place is called wastāni, a lukewarm place preparing the entrance to the inner part, the hot room, called ğuwwānī. Inside the hot room, one or several secluded rooms, halwa, permit customers to perform intimate practice, such as shaving themselves. If we observe the plans reported by David and Mounif (2014, 804-15), we notice that every hammām was built to be a pre-ordered place: the path that the customer was supposed to follow to have access to the places was inscribed in the architecture itself. A first big room has the function to permit to the user to prepare himself, undress and wear a loincloth; later a medium lukewarm room introduces the customer to the pleasure of the hot bath, here both hot and cold water are available, but the room is not completely heated; finally, the last step is to enter in the hot room, usually smaller than the others, completely heated with the access to private rooms and/or steam rooms. Considering this path and looking at the architecture of a hammām, I can affirm that the way which takes customers inside the bath is pre-ordered, since the architecture proposes a series of rooms following each other, between which there is only one opening, a threshold, which directs and forces the client's way. It is like a ritual developing itself from outside to inside. However, even if its path is pre-ordered, the hammām presents a certain degree of flexibility too. This is true above all regarding the external places compared to the internal nucleus. There, different activities can be performed, especially at the

26 al-Ġuzūlī (2006, 2:312-4) and al-Munāwī (1987, 61-3) describe the hammām as sequence of rooms, in which the heat raises gradually: the first and cold room is called maslah, then the progression from cold to hot follows the progression of the rooms, from al-bayt al-awwal until al-bayt al-tālit. This path is also described in a medical work dating back to the beginning of tenth/sixteenth century written by al-Qūșūnī, chief of the physicians of Egypt. On this point see Denoix $(2014,1028-33)$. This nomenclature was used also in modern Egypt, as pointed out by Pauty (1933, 23-41) in his description of the hammäms in Cairo. Also, Grotzfeld (1970, 26-44). 
end of the bath experience. This is why being pre-ordered in its path, the hammām is also semi-determined in its usage, with an increasing degree of 'pre-orderedness' growing as we access the inner part.

Thus, we must consider the hammām a space strongly invested of cultural and social values. These values play an important role in each literary representation, becoming an essential element of the narration. First of all, for they represent the encyclopaedia of both the model reader and the empirical reader of the work (Eco [1979] 2006). Secondly, these values, being a part of common acquaintances, act in the text and play an essential role in the understanding thereof, bringing a key to interpretation. It follows that the space itself, with its values, is to be considered a text in its own. This epigram is a text within a text within a text. Given that the space is a text too, and not a mere circumstance, we should be able to analyse it detecting the actantial roles and the narrative schema. What is the actantial role which can be assigned to the hammām?

Greimas proposes a classification of spaces in either topical, namely "the place where the transformation in question takes place" (Greimas 1988,82 ) - i.e. the narrative program, the conjunction between Subject and Object -, or heterotopical, namely "the preceding and following places enclosing it" (82). The topical space is in turn to be divided into utopian, which is the space in which the performance is performed, or paratopical, in which the subject acquires the competences in order to be able to achieve the performance. The space of the manipulation is the paratopical space. The whole hammām described in this epigram is, at the same time, the heterotopical and topical space. As we have seen above, the bath is commonly divided into several places, in general three, corresponding to particular uses. If we imagine the scene depicted in the epigram, the external part of the hammām is the place in which the contract between Addresser and Subject is drawn up, the space in which the manipulation from the Addresser takes place. Following the path towards the innermost of the hammām the Subject acquires the competence, the Object in its ambivalence is revealed, the Addresser provides the Subject with the modality of knowing, while the Subject acquires the wanting-to-do. The space of the performance, the utopian space, in which the conjunction between the Subject and the Object of value is possible, is the halwa, the innermost of the hammām, a part thereof, but contemporaneously separated, a place of modesty or debauchery.

On closer inspection, we notice that the narrative trajectory of the Subject develops within the space following the pre-ordered path determined by the structure of the hammām. Thus, I can affirm that the narrative trajectory is made possible especially thanks to the spatial structure of the site in which the Subject acquires the necessary virtualising and actualising modal competencies and acts to obtain the conjunction with the Object of value, following a path on the axis outside > inside. The Space is itself a 
narrative trajectory. The places crossed from time to time are limits, as per the definition given by Hammad (2004), namely they are established on a contractual basis. Considering the topical space of the performance - i.e. the secluded place -, its own architectural structure shows us how it can be accessed only after the crossing of a threshold, this being crossed only after having acquired an 'authorisation'. Hammad (2004) underlines that the granting of an 'authorisation' to cross a threshold is referred to a third actantial role - a third Subject $\left(\mathrm{S}_{3}\right)_{-}$, who is not the Subject neither the Object, ${ }^{27}$ but in our epigram, things become complicated.

In $\mathrm{T}_{1}$, the Subject aspires to the conjunction with the Object of value 'shaving'. In this case such an intimate practice can only occur within a room, which allows one to not expose the nude body publicly, the room of which was prepared on purpose by the attendant Mùsà. The access to the room is controlled by the attendant himself, the actor who plays in the narrative schema of $\mathrm{T}_{1}$ the actantial role of the Helper, while in $\mathrm{T}_{3}$, he plays the actantial role of $\mathrm{S}_{3}$ who controls the threshold space and allows its crossing. In $\mathrm{T}_{2}$, the Subject acts in order to be joined with the Object 'sexual intercourse' identified in Mùsà. Thus, in the narrative schema of $\mathrm{T}_{2}$ Mùsà is not the Helper anymore, but the Object of value himself, and he plays also the actantial role $\mathrm{S}_{3}$ in $\mathrm{T}_{3}$, allowing the Subject to cross the threshold of the room in which the performance can be performed. In both cases, as Hammad (2013) pinpoints, the space is not a mere circumstantial element, rather it is possible to analyse it using the actantial categories. In this specific case, the secluded place, utopian place, is in both $\mathrm{T}_{1}$ and $\mathrm{T}_{2}$ the spatial actor who plays the actantial role of the Helper, since the performance is possible in it, but not outside it, the room-Helper provides the Subject with the modal competence being-able-to-do and assists the Subject in performing his narrative program.

Consequently, if the space is a text, with its charge of narrative schema, I agree with Marrone (2001), who highlights the presence for each given

27 Hammad (2004) describes the limit as a space which implies seven actantial roles. The limit divides two Spaces $\left(E_{1}\right.$ and $\left.E_{2}\right)$ in which two Subjects act $\left(S_{1}\right.$ and $\left.S_{2}\right)$, the threshold between them of which is the place in which one of these Subjects expresses the will to cross it and join himself with the other space. The modality being-able-to-cross is provided by another actant Subject $\left(\mathrm{S}_{3}\right)$ - it does not matter if the actors coincide -, while the threshold itself is to be considered as a share of Space $\left(E_{3}\right)$, different from $E_{1}$ and $E_{2}$. Hammad identifies the Spaces $E_{1-3}$ as Object with which the Subject is joined or disjointed, and the crossing of the threshold as the wanting-to-be-joined with another Object. Since two spaces are divided by a threshold and it is the only way to have access to the other space, another division between the two spaces, uncrossable, has to be considered. For example, a wall which prevents the access from $E_{1}$ to $E_{2}$ is an uncrossable limit, but it is neither $E_{1}$ nor $E_{2}$, and cannot be the threshold itself $\mathrm{E}_{3}$, thus it is another actantial role: $\mathrm{E}_{4}$. 
space of a model user, ${ }^{28}$ just like the Model Reader (Eco [1979] 2006). This is why if we consider the Object in $\mathrm{T}_{1}$, taking place in $\mathrm{T}_{3}$, the action of shaving conforms to the expectations of a model user, who enters a hammäm having the intention to shave himself. On the other hand, in $\mathrm{T}_{2}$, taking place in $\mathrm{T}_{3}$, the Object 'sexual intercourse' does not conform to the expectations of a model user, given that coitus in a hot bath is not only forbidden, but also considered dangerous for health. This violation of social, medical, and ethical norms involves a resemantization of the whole $\mathrm{T}_{3}$.

This causes an effect of estrangement, which can be better understood considering the two different perspectives in the definition of 'discrete unit of space', a topos. Hammad underlines how the definition of topos as "une portion d'espace, découpée dans le continuum spatiale, identifiable par ce qu'une action s'y accomplit" $(2013,9)$ (a share of space, cut out in the spatial continuum, identifiable by the action that happens in it) is not totally satisfying. Instead, he suggests that one consider what can be made of and with the space, rather than within, since the space can change its function on the basis of its final users. In other words, "la valeur de l'espace intermédiaire ne provient pas de ce qui s'y passe [...], mais du programme ultérieur qu'il permet de réaliser" (12) (the value of the intermediate space does not come from what happens there [...], but from the further program which allows to realise). From this starting point, Hammad describes two perspectives: the internal perspective "ou l'homme inséré dans l'espace physique" (15) (or the man inserted into the physical space), and the external perspective "ou l'espace physique pris en charge par l'espace social" (15) (or the social space which takes charge of the physical space). According to the internal perspective, in $T_{1}$ the form of the action 'shaving' $\left(A_{1}\right)$, which relates the Subject (S) and the Space (E) - the secluded room -, is $A_{1}(E, S)$, i.e. the secluded room permits to someone to shave himself. In the external perspective the topos is brought in circulation among several Subjects, and its form can be described as $\mathrm{A}_{1}\left(\mathrm{~S}_{1}, \mathrm{E}, \mathrm{S}_{2}\right)$. The topos halwa is architecturally designed for the action of shaving, being permitted from a social point of view. Its function is thus recognised and the topos can circulate among Subjects. On the other hand, in $\mathrm{T}_{2}$ the action is 'having a sexual intercourse' $\left(A_{2}\right)$ and the form $A_{2}(E, S)$ expression of the internal perspective cannot permit any circulation of the topos as in the form $A_{2}\left(S_{1}, E, S_{2}\right)$, since there is no social recognition of the action which takes place in it.

28 "Questi ultimi sono figure narrative previste in anticipo nella struttura degli spazi, i quali si fanno carico di quelle forme di comportamento che i luoghi implicitamente richiedono" (Marrone 2001, 321) (The latter are narrative figures foreseen in advance in the structure of the spaces, which take charge of those forms of behaviour that the places implicitly require). 


\section{Conclusions}

At first glance this epigram seems to be a mere funny pun, nothing more than a joke. However, in my analysis I tried to demonstrate how these two lines, perceived as a singular text, are in fact a twine of texts due to the presence of the tawriya-word. To use a metaphor, the epigram is like a play of Chinese boxes, since the text perceived at the first reading $\left(\mathrm{T}_{0}\right)$ contains in itself other texts $\left(\mathrm{T}_{1-3}\right)$. The first explanation to this 'embedding' is found in the power of the tawriya to play the role of the disjunctor, being the point of departure of a second reading entailing a second text based on and legitimised by the first - i.e. $\mathrm{T}_{1}$ and $\mathrm{T}_{2}-$. The effectiveness of the disjunctor relies on the competence of the reader, who, in turn, should be able to understand both meanings of the tawriya-word in order to perceive both texts in their relationship with one another. Here the reader enters the ring, and faces a significant choice: razor, bath attendant, or both of them? We discover the importance of this choice when taking into account the narrative schema. In every narrative, the actantial figure of the manipulatory Addresser provides the Addressee-Subject with the modal competencies and values permitting him the performance. However, the Object indicated by the manipulatory Addresser is ambiguous, thus the completion of the actantial role is to be attributed to the reader, who is able to assign a value to the Object by his choice. Moreover, the performance does not take place and consequently the actantial figure of the judicatory Addresser is not expressed in the textual level. Once again, it is the reader who expresses this actantial role, since he is in charge of the final sanction depending on the Object of value and the hypothetical performance. In turn, the final sanction depends on the social norms shared by the reader. According to the Object, the performance is a transgression or a deviancy on the basis of the conflicts described with the help of the semiotic square. These conflicts depend on the perception of the action within the space in which it takes place. That is why the space hammäm plays an essential role in the definition of the aesthetic success of the epigram. Every action, real or hypothetical, should be considered in the frame of the common knowledge about what is permitted and forbidden in a hammām. The space, therefore, can be analysed as a narrative too: it is a third text $\left(\mathrm{T}_{3}\right)$, which has its own narrative schema and actantial figures. The narrative schemas of $T_{1-3}$ merge together and concur in the decode of the whole $\mathrm{T}_{0}$. It is therefore clear how the role of the reader is essential to complete the narrative trajectory of the Subject towards his Object of value, integrating himself in the narrative schema. Far from being merely an easy joke, this epigram mirrors the whole encyclopaedia of a common reader about hammām practice and social norms related to it. Texts are powerful. They 'act' the reader and anticipate his interpretation. But a question remains: could we apply the tools of semiotics towards a general 
redefinition of tawriya-poetry and aesthetic taste during the Mamluk age? What I have outlined so far anticipates such an application, which would, in my opinion, prove to be fruitful in the analysis of such "open works" (Eco [1979] 2006).

\section{Bibliography}

\section{Primary sources}

Abū l-'Atāhiya (1909). al-Anwār al-zāhiyya fī dīwān Ab̄̄ l-Atāhiya. Ed. Louis Cheikho. Bayrūt: al-Maṭba'a l-kātūlīkiyya.

Abū l-'Atāhiya (1999). Dīwān Abī l-'Atāhiya. Ed. Garīd al-Šayh. Bayrūt: Mu'assasat al-a'lamī li-l-maṭū'āt.

al-'Alawī l-Yamanī (1914). al-Ṭirāz al-mutạ̣ammin li-asrār al-balāga wa'ulūm hạā'iq al-i'ğāz, vol. 2. al-Qāhira: Dār al-kutub al-hudaywiyya.

al-'Asqalānī, Šihāb al-Dīn Aḥmad b. 'Alī ibn Hağar (1972). al-Durar alkāmina fī a'yān al-mi'a al-tāmina, vol. 1. Ed. Muhammad 'Abd al-Mu'īd Hāan. Haydārābād: Maṭba'a mağlis dāirat al-ma‘ārif al-'uțmāniyya.

Faḩr al-Dīn al-Rāzī (2004). Nihāyat al-īğāz fī dirāyat al-i'ǧāz. Ed. Nașr Allāh Hāğīi Muftī Ūg̀là. Bayrūt: Dār șādir.

al-Ǵuzūlī, 'Alā' al-Dīn 'Alī b. 'Abd Allāh al-Bahā'ī (2006), Mațāli' al-budūr fī manāzil al-surūr, vol. 2. al-Qāhira: Maktabat al-țaqāfa al-dīniyya.

al-Haymī l-Kawkabānī, Šihāb al-Dīn Aḥmad b. Muḥammad (1986). Hadā'iq al-nammām fī l-kalām 'alà mā yata'allaq bi-l-ḥammām. Ed. 'Abd Allāh Muḥammad al-Hibšì. Bayrūt: al-Dār al-yamaniyya.

Ibn Hiğğa l-Ḥamawī, 'Alī b. 'Abd Allāh (2001). Hizānat al-adab wa-ḡāyat al-arab. 5 vols. Ed. Kawkab Diyāb. Bayrūt: Dār Șādir.

Ibn Hiğğa l-Hamawī, 'Alī b. 'Abd Allāh (2011). Kašf al-lițām 'an wağh altawriya wa-l-istiḩdām. Ed. Muḥammad Nāğī Ibn 'Umar. Bayrūt: Dār al-kutub al-ilmiyya.

Ibn al-'Imād, Šihāb al-Dīn Abū l-Falāḥ 'Abd al-Hayy (1992). Šaḍarāt aldahab fī ahbār man dahab, vol. 8. Ed. 'Abd al-Qādir Maḥmūd al-Arnā'ūṭ. Dimašq: Dār Ibn Katīir.

Ibn Mālik, Abū 'Abd Allāh Badr al-Dīn (2001). al-Miṣbāḥ fī l-ma‘ānī wal-bayān wa-l-badī'. Ed. 'Abd al-Hamīd Hindāwī. Bayrūt: Dār al-kutub al-'ilmiyya.

Ibn Ma'ṣūm, 'Alī Ḩān Ṣadr al-Dīn Ibn al-Amīr Niẓām al-Dīn Aḥmad (196869). Anwār al-rabī' fī anwā‘ al-badī‘, vol. 1. Ed. Šākir Hādī Šukr. al-Naǧaf: Maṭba'at al-nu'mān.

al-Maqrīzì, Taqī l-Dīn Aḥmad b. 'Alī (2002). Durar al-‘uqūd al-farīda fī tarāğim al-a'yān al-mufīda, vol. 1. Ed. Maḥmūd al-Ğalīlī. Bayrūt: Dār al-ġarb al-islāmī. 
al-Mawsū'a l-fiqhiyya (1983). Al-Kuwayt: Wizārat al-awqāf wa-l-šu'ūn alislāmiyya.

al-Munāwī, 'Abd al-Ra'ūf (1987). al-Nuzha l-zahiyya fī aḥkām al-ḥammām al-šar'iyya wa-l-țibbiyya. Ed. 'Abd al-Hamīd Ṣāliḥ Hamdān. Al-Qāhira: al-Dār al-mișriyya l-lubnāniyya.

al-Nābulusī, 'Abd al-Ġanī (1882). Nafaḥāt al-azhar 'alà nasamāt al-asḥār fī madh al-nabiyy al-muḩtār. Bayrūt: 'Alam al-kutub. al-Qāhira: Maktabat al-Mutanabbī.

Ibn Qāọī Šuhba al-Asadī l-Dimašqī, Taqī l-Dīn Abū Bakr b. Aḥmad (1977). Tārīh̆ Ibn Qāọī Šuhba, vol. 1. Ed. 'Adnān Darwīš. Damas: Institut français de Damas.

al-Qazwīnī, Ğalāl al-Dīn Abū 'Abd Allāh Muḥammad b. 'Abd al-Raḥmān b. 'Umar (2007). al-Ị̣̂̄ḥ fī 'ulūm al-balāga. Ed. Muhammad 'Abd al-Qādir al-Fāḍilī. Bayrūt: al-Maktaba l-‘așriyya.

al-Rāgìb al-Iṣfahānī (2012). Muhāọarāt al-udabā' wa-muhāwarāt al-šu'arā' wa-l-bulagā', vol. 3. Ed. Riyāọ 'Abd al-Hamīd Murād. Bayrūt: Dār șādir. al-Ṣafadī, Șalāḥ al-Dīn b. Aybak (2009). Al-Ġayt al-musağğam fī šarḥ lāmiyyat al-'ağam, vol. 1. Ed. Șalāḥ al-Dīn al-Hawwārī. Bayrūt: Maktabat al-‘așriyya.

al-Ṣafadī, Șalāh al-Dīn b. Aybak (2013). Faḍ̣ al-ḥitām 'an al-tawriya wa-listiḩdām. Ed. 'Abbās Hān̄̄ al-Čarrāhn. Bayrūt: Dār al-kutub al-'ilmiyya. al-Sakkākī, Abū Ya'qūb Yūsuf b. Muḥammad b. 'Alī (2014). Miftāḥ al-'ulūm. Ed. 'Abd al-Hamīd Hindāwī. Bayrūt: Dār al-kutub al-'ilmiyya.

Al-Siyālkūtī, 'Abd al-Hakīm Šams al-Dīn (2012). Hāšiyat al-Siyālkūtī 'alà kitāb al-muṭawwal li-l-Taftāzānī, vol. 2. Ed. Muhammad al-Sayyid 'Uțmān. Bayrūt: Dār al-kutub al-'ilmiyya.

al-Subkī, Bahā' al-Dīn Abū Hạ̄mid Aḥmad b. Taqī l-Dīn 'Alī (2001). 'Arūs al-afrāḥ fī šarḥ talḥịs al-miftāḥ, vol. 2. Ed. Halīl Ibrāhīm Halīl. Bayrūt: Dār al-kutub al-'ilmiyya.

al-Suyūṭì, Ğalāl al-Dīn 'Abd al-Raḥmān b. Abī Bakr (2015). Šarh 'uqūd al-ğumān fī 'ilmay al-ma'ānī wa-l-bayān. Ed. Muhamamad 'Uțmān. AlQāhira: al-Maktaba al-azhariyya li-l-turāt.

Ibn Tağrī Bird̄̄, Ǧamāl al-Dīn Abū al-Mahāsin Yūsuf (1984). al-Manhal alșāfī wa-l-mustawfī ba'da l-wāfì, vol. 2. Ed. Muḥammad Amīn Muhamamad. al-Qāhira: al-Hay'a l-Mișriyya l-‘āmma li-l-kitāb.

Ibn Tağrī Birdī, Ğamāl al-Dīn Abū al-Mahāsin Yūsuf (1992). al-Nuğūm alzāhira fī mulūk Miṣr wa-l-Qāhira, vol. 12. Ed. Muhạmmad Husayn Šams al-Dīn. Bayrūt: Dār al-kutub al-'ilmiyya.

Ibn Tag்rī Birdī, Ğamāl al-Dīn Abū al-Maḥāsin Yūsuf (1998). al-Dalīl al-šāfī 'alà l-Manhal al-ṣāfī, vol. 1. Ed. Fahīm Muhammad Šaltūt. al-Qāhira: Mațba'at dār al-kutub al-mișriyya.

al-Taftāzānī, Sa'd al-Dīn Mas'ūd b. 'Umar b. 'Abd Allāh (2013). al-Muṭawwal šarh talh̄iṣ miftāḥ al-'ulūm. Ed. 'Abd al-Hamīd Hindāwī. Bayrūt: Dār alkutub al-'ilmiyya. 
al-Tahānawī, Muḥammad A'lā (1996). Kaššāf ișțilahāt al-funūn wa-l-'ulūm. Ed. 'Alī Daḥūğğ, 'Abd Allāh al-Ḩālidī, Ǧūrğ Zaynātī. Bayrūt: Maktaba Lubnān Nāširūn.

\section{Secondary sources}

Aljared, Amal (2017). “The Isotopy Disjunction Model”. Attardo 2017, 64-79. Attardo, Salvatore (1989). "Disgiunzione comica referenziale e verbale: analisi tassonomica e statistica di un corpus di barzellette". Studi italiani di linguistica teorica ed applicata, 18(3), 479-93.

Attardo, Salvatore (1994). Linguistic Theories of Humor. Berlin; New York: Mouton de Gruyter.

Attardo, Salvatore (ed.) (2017). The Routledge Handbook of Language and Humor. New York and London: Routledge.

Audebert, Claude; Bakhouch, Mohamed (2014). "Les rêveries d'un lettré yéménite sur le hammam. Les aspects sociaux et artistiques dans le discours sur le hammam dans Hadā'iq al-nammām fī l-kalām 'alà mā yata'allaq bi-l-ḥammām de Aḥmad b. Muḥammad al-Haymī al-Kawkabānī (m. 1153/1741)". Boussac 2014, 4, 1081-111.

Bauer, Thomas (2003). "Communication and Emotion: The Case of Ibn Nubātah's Kindertotenlieder". Mamlūk Studies Review, 7, 49-96.

Bauer, Thomas (2005). "Mamluk Literature: Misunderstandings and New Approaches". Mamlūk Studies Review, 9(2), 105-32.

Bauer, Thomas (2007). “Arabische Kultur”. Ueding, Gert, (Hrsg.), Historisches Wörterbuch der Rhetorik, Bd. 8. Tübingen: Max Niemeyer Verlag, 111-37.

Bauer, Thomas (2013a). “'Ayna hādhā min al-Mutanabbī!' Toward an Aesthetics of Mamluk Literature". Mamlūk Studies Review, 17, 5-22.

Bauer, Thomas (2013b). "Mamluk Literature as Means of Communication". Conermann, Stephan (ed.), Ubi sumus? Quo vademus? Mamluk Studies - State of the art. Bonn: V\&R Unipress Bonn University Press, 23-56.

Bauer, Thomas (2014a). "Dignity at Stake: Mujūn Epigrams by Ibn Nubāta (686-768/1287-1366) and His Contemporaries". Talib, Adam et al. (eds.), The Rude, the Bad and the Bawdy. Essays in honour of Professor Geert Jan van Gelder. Cambridge: Gibb memorial trust, 160-85.

Bauer, Thomas (2014b). "Male-Male Love in Classical Arabic Poetry". Mccallum, E.L.; Tuhkanen, Mikko (eds.), The Cambridge History of Gay and Lesbian Literature. Cambridge: Cambridge University Press, 107-24.

Bauer, Thomas (2016). "Ambiguität in der klassichen arabischen Rhetoriktheorie". Auge, Oliver; Witthöft, Christiane (Hrsg.), Ambiguität im Mittelalter. Formen zeitgenössischer Reflexion und interdisziplinärer Rezeption. Berlin: De Gruyter, 21-47. 
Benkheira, Mohammed Hocine (2007). “Hammam, nudité et ordre moral dans l'islam médiéval (I)". Revue de l'histoire des religions, 224(3), 319-71.

Benkheira, Mohammed Hocine (2008). "Hammam, nudité et ordre moral dans l'islam médiéval (II)". Revue de l'histoire des religions, 225(1), 75-128.

Bonebakker, Seeger Adrianus (1966). Some Early Definitions of the Tawriya and Șafadī's Faḍ̣ al-xitām 'an at-tawriya wa-'l-istixdām. The Hague; Paris: Mouton \& Co.

Boussac, Marie-Françoise et al. (éds.) (2014). 25 siècles de bain collectif en Orient. Proche-Orient, Égypte et péninsule Arabique. 4 vols. Le Caire: Institut français d'archéologie orientale.

Bouhdiba, A. (1964). "Le Hammam. Contribution à une psychanalyse de l'Islam”. Revue Tunisienne de Sciences Sociales, 1, 7-14.

D’Amora, Rosita; Pagani, Samuela (a cura di) (2011). Hammam. Le terme nell'Islam. Firenze: Leo S. Olschki.

David, Jean-Claude (2014). "Le hammam, du public à l'intime. Mort annoncée et nécessaire évolution - Le Cas d'Alep". Boussac et al. (2014), 3: 785-818.

Denizeau, Valentine (2014). "Le hammam, un outil de promotion urbaine dans les villes du domaine mamelouk. (Le Caire, Damas, Alep)”. Boussac et al. (2014), 3: 727-43.

Denoix, Sylvie (2014). "Un discours sur le hammam au XVIe s. Pratique médicale et expression d'une norme savant". Boussac et al. (2014), 4: 1025-45.

Eco, Umberto [1979] (2006). Lector in fabula. La cooperazione interpretativa nei testi narrativi. Milano: Bompiani.

Ghersetti, Antonella (1998). “Quelques notes sur la définition canonique de Baläga". Orientalia Lovaniensia Analecta, Philosophy and Arts in the Islamic World, 57-72.

Greimas, Algirdas Julien (1966). Sémantique structurale. Recherche de Méthode. Paris: Larousse.

Greimas, Algirdas Julien (1988). Maupassant. The Semiotics of Text. Practical Exercises. Trans. Paul Perron. Amsterdam, Philadelphia: John Benjamins Publishing Company. Trans. of Maupassant. La sémiotique du texte: exercices pratiques. Paris: Éditions du Seuil, 1976.

Greimas, Algirdas Julien; Courtés, Joseph (1982). Semiotics and Language. An Analytical Dictionary. Trans. Larry Crist et al. Bloomington: Indiana University Press. Trans. of: Sémiotique. Dictionnaire raisonné de la théorie du language. Paris: Hachette, 1979.

Greimas, Algirdas Julien; Rastier, François (1968). "The Interaction of Semiotic Constraints". Yale French Studies. Game, Play, Literature, 41, 86-105.

Grotzfeld, Heinz (1970). Das Bad im arabisch-islamischen Mittelalter. Eine kulturgeschichtliche Studie. Wiesbaden: Otto Harrassowitz. 
Hammad, Manar (2004). “Présupposés sémiotiques de la notion de limite” [online]. Documenti di Lavoro e pre-pubblicazioni, 330-2. Urbino: Centro Internazionale di Semiotica e Linguistica, 7-16. URL https://www. academia.edu/2024385/Pr\%C3\%A9suppos\%C3\%A9s_s\%C3\%A9miotiques de la notion de limite (2018-02-15)

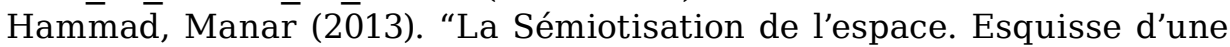
manière de faire" [online]. Actes Sémiotiques, 116, 1-64. URL http:// epublications.unilim.fr/revues/as/2807 (2018-02-14).

Iser, Wolfgang (1980). The Act of Reading. A Theory of Aesthetic Response. Baltimore and London: The Johns Hopkins University Press. Trans. of Der Akt des Lesens. Theorie ästhetischer Wirkung. München: Wilhelm Fink, 1976.

Koetschet, Pauline (2014). “Quelques aspects du bain dans la médecine arabe médiéval. Conservation et restauration de la santé". Boussac et al. 2014, 4: 1011-24.

al-Lahībī, Husayn 'Abd al-'Āl (2014). "Šihāb al-Dīn bin al-'Ațtār alDunaysarī hayātu-hu wa-mā tabaqqà min ši'ri-hi dirāsa wa-tawtīiq" [online]. Adāb al-Kūfa, 20(1), 219-94. URL http://Www.uokufa.edu.iq/ journals/index.php/kufa_arts/article/view/3035 (2018-01-22).

Larcher, Pierre (2009). “Mais qu'est-ce donc que la baläga?”. Woerther, Frédérique (ed.), Literary and philosophical rhetoric in the Greek, Roman, Syriac and Arabic worlds, Hildesheim: Georg Olms, 197-213.

Larcher, Pierre (2013). "Arabic Linguistic Tradition II: Pragmatics". Owens, Jonathan (ed.), The Oxford Handbook of Arabic Linguistics. Oxford: Oxford University Press, 185-212.

Marrone, Gianfranco (2001). Corpi sociali. Processi comunicativi e semiotica del testo. Torino: Einaudi.

Marrone, Gianfranco (2014). The Invention of the Text. Trans. Sara Anselmi, Dario Mangano. S.l.: Mimesis International. Trans. of: L'invenzione del testo. Bari: Laterza, 2010.

Melchert, Christopher (2014). "Public Baths in Islamic Law". Boussac et al. (2014), 4: 1001-24.

Minsky, Marvin (1974). "A Framework for Representing Knowledge" [online]. MIT-AI Laboratory Memo, 306. URL http://hdl.handle. net/1721.1/6089 (2018-10-15)

Morin, Violette [1966] (1981). “L'histoire drôle”. Communications 8. Paris: Éditions du Seuil, 108-25.

Pauty, Edmond (1933). Les Hammams du Caire. Le Caire: Imprimerie de l'Institut français d'archéologie orientale.

Szombathy, Zoltan (2013). Mujūn. Libertinism in Mediaeval Muslim Society and Literature. Cambridge: Gibb Memorial Trust.

Talib, Adam (2018). How Do You Say 'Epigram' in Arabic? Literary History at the Limits of Comparison. Leiden: Brill. 
Van Gelder, Geert Jan (2008). “The hammām: a Space between Heaven and Hell". Quaderni di Studi Arabi, n.s., 3, 9-24.

Van Gelder, Geert Jan (2012). "Epigram, classical Arabic" [online]. Encyclopaedia of Islam, THREE. Ed. by Kate Fleet et al. DOI 10.1163/15733912_ei3_COM_26197 (2018-01-18).

Zakharia, Katia (2014). "Mésaventures au hammam". Boussac et al. (2014), 4: 1113-45. 